\title{
Ptahshepses standing or walking sheltered by the sunshades in his recently discovered tomb at Saqqara
}

\section{Introduction}

Ptahshepses' tomb was discovered in 2010 by the mission of the Egyptian Supreme Council of Antiquities (SCA), under my supervision with my colleague Ali El-Batal. It is situated in the Gisr el-Mudir site, west of the Step Pyramid and Unas' Pyramid at Saqqara. ${ }^{1}$ It is dated to the end of the Fifth and the beginning of the Sixth Dynasty, Unas' and Teti's reigns. The owner of the tomb had fifty-one titles and epithets such as: inspector of the royal domain, inspector of the great house, inspector of the robing-room, lector priest, overseer of the two granaries, overseer of the two treasuries, overseer of the two houses of gold, overseer of the two workshops, overseer of the linen house, overseer of the commissions of the great house, $h m-n \underline{t} r$-priest of (the pyramid) 'perfect-is-Izezi', $h m-n \underline{t} r$-priest of (the pyramid) 'perfect-are-the places-of-Unas', hm-ntr -priest of (the pyramid) 'Steadfast-are-the places-of-Teti', etc. This tomb consists of three levels. The top one represents its core, surrounded by an enclosure wall. The second level represents its chapel, which consists of two rock cut courts (the first of which is open and the second is vaulted) and an offering room, cased with limestone from Tura and decorated with daily life scenes. The third level represents its burial chamber, which is also decorated. The offering room is decorated with daily life scenes; fishing, fowling, farming, pastures, poultry-yard, dancing, music, food preparation and presentation, workshop activities (metal workers, making statues, leather workers, etc), relaxation and body care (bed and chair preparation, shaving, manicure and pedicure) and transporting the funeral furniture. It has some intersting, colourful and unique scenes and inscriptions.

\section{The tomb owner sheltered by the sunhades}

The tomb owner is depicted twenty-five times in the offering room in different forms and positions. In one of these scenes, on the east wall of the offering room and south of the entrance (Figure 1), the tomb owner is shown standing or walking sheltered by two sunshades. $\mathrm{He}$ is facing right (south). He wears a shoulder-length wig and a straight beard, a collar and a triangular kilt. His arms are extended beside his body; his left hand is opened and touches his kilt, while his right hand holds a flywhisk (Figure 2). There is a hieroglyphic text in front of him:

$$
\neq \text { 迎 }
$$

'We worked in this site over three years 2008-2011 and discovered many mastabas and rock cut tombs. We have published some of these tombs: Ali ElBatal, Fatma Khattab and Saleh Soleiman, The Tombs of Ia-Maat and Others, The Gisr El-Mudir Cemetery at Saqqara, vol. I (Cairo, 2012); Saleh Soleiman and Ali El-Batal, The Tombs of Nefersut, Weserkafankh, Shepseskafankh and Others, The Gisr El-Mudir Cemetery at Saqqara, vol. II (Cairo, 2015); Saleh Soleiman and Ali El-Batal, Coffins and Architectural Elements, The Gisr elMudir Cemetery at Saqqara, vol. III (Cairo, 2015), Saleh Soleiman and Ali El-Batal, The Tomb of Ptahshepses, Part I, The Tomb Owner, Architecture and Dating of the Tomb, The Gisr el-Mudir Cemetery at Saqqara, vol. IV (Cairo, 2015); Saleh Soleiman and Ali El-Batal, False Doors, The Gisr el-Mudir Cemetery at Saqqara, vol. V (Cairo, 2015).
Volume 3 Issue 3 - 2018

\author{
Saleh Soleiman \\ Department of Egyptology, Damietta University, Egypt
}

Correspondence: Saleh Soleiman, Department of Egyptology, Damietta University, Egypt, Email saleh_suleiman82@yahoo.com

Received: January 24, 2018 | Published: June 05, 2018

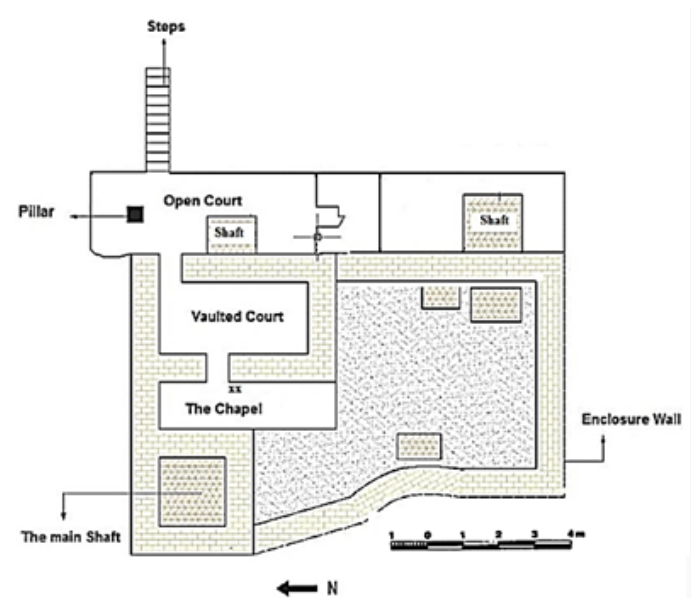

Figure I The plan of Ptahshepses' tomb (super-structure), "XX"= Location of the scene of Ptahshepses standing sheltered by sunshades on the east wall of the chapel.

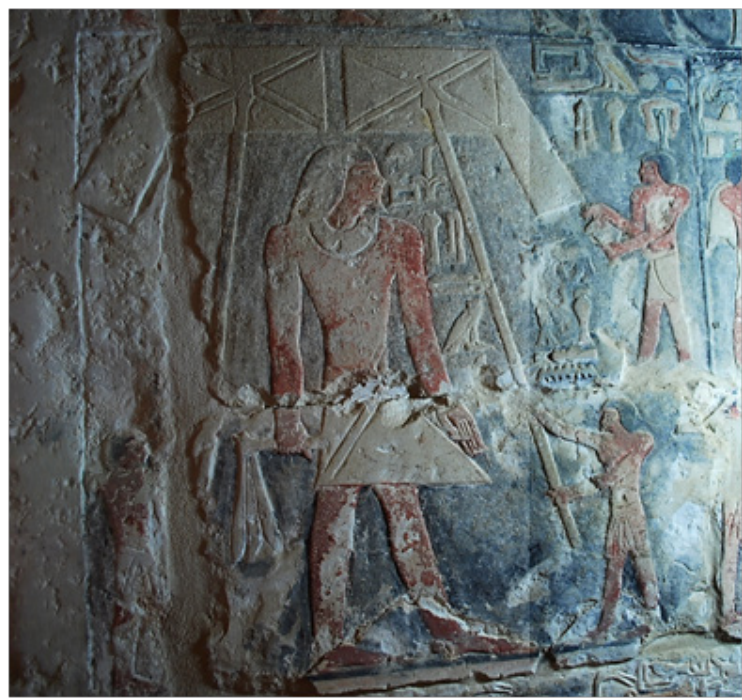

Figure 2 Ptahshepses standing sheltered by sunshades. 
Inspector of the royal domain, ${ }^{2}$ Tjemi/Themi. ${ }^{3}$ There is a person, standing in front, facing him and looking left. He is wearing a wig and a short and tight kilt. His arms are bent in front of him and he is holding a sensor with incense. There are two horizontal and one vertical line of hieroglyphs above and in front of him:

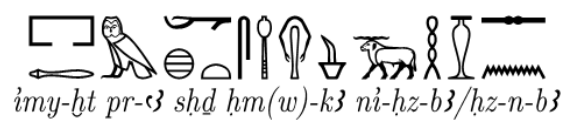

Under supervision of the great house (the Palace) ${ }^{4}$ and inspector of funerary priests, ${ }^{5}$ Nyhesba/Hes-n-ba, there are two sunshade carriers around the tomb owner. Each one wears a striped kilt and holds with his hands the pole of the sunshade. They are trying to offer the shade for Ptahshepses to protect him from the sun's heat.

\section{Commentary}

\section{The titles and names of the tomb owner and his attendants}

The tomb owner's title, shd $\underline{d}$ r-nzwt, was mentioned Forty-five times in this tomb. It seems that Ptahshepses was particularly proud of the title shd pr-nzwt and wanted to emphasize it as much as he was able. It is mentioned more than any other title: 32 times in the chapel and 13 times in the burial chamber. His two sons also have this title. So it would appear that this is the most favored by the family. In addition to this, he added the element $m 3 c$ to the title to express the reality of holding it. This title, shd $p r-n z w t$, was one of twenty-four titles and epithets of the deceased that were associated with the king and his possessions during his life or after his death (palace, pyramid ...etc). These titles seem to confirm that the tomb owner had direct relations and contacts with the king under whom he serviced. These functions kept him close to the person of the king. We have in the Old Kingdom only a few individuals who have this title shd pr-nzwt, such as Khentika/Ikhekhi and one of his attendants, ${ }^{6}$ Shedyptah, ${ }^{7}$ Nyankhnefertem, ${ }^{8}$ in addition to Ptahshepses and his two sons. It is a rare title. The earliest mention of it is in the recently discovered tomb of Ptahshepses, which is dated to Unas' and Teti's reigns, but the other examples are dated to Pepy I or Pepy II. The tomb owner's name, Tjemi/Themi, was attested for males in some Old Kingdom tombs at Abusir and Saqqara. This name was written in this previous form in all parts of Ptahshepses' tomb. It is mentioned in the texts of the tomb that Themi is the $r n$ nfr 'the good name' of the deceased. It was given to him by his mother, Hemetra, according to the texts of the burial chamber recorded on the north wall of the sarcophagus

${ }^{2}$ Dilwyn Jones, An Index of Ancient Egyptian Titles, Epithets and Phrases of the Old Kingdom, BAR 866 [2] (Oxford, 2000), 926 [3406].

${ }^{3}$ Hermann Ranke, Die ägyptischen Personennamen, Band I, Verzeichnis der Namen (Glückstadt, 1935), 391 [1]; Katrin Scheele-Schweitzer, Die Personennamen des Alten Reiches, Altägyptische Onomastik unter lexikographischen und sozio-kulturellen Aspekten (Philippika, 2014), 733 [3702].

${ }^{4}$ Jones, Index, 285 [1032].

5Jones, Index, 943 [3475].

${ }^{6}$ Thomas James and Michael Apted, The Mastaba of Khentika Called Ikhekhi, Archaeological Survey of Egypt, Thirtieth Memoir (London, 1953), 9; Henry Fischer, Varia Nova, Egyptian Studies III (New York, 1996), 1-2, fig. 1.

${ }^{7}$ Cecil Firth and Battiscombe Gunn, Excavations at Saqqara, Teti Pyramid Cemeteries, Service des Antiquités de l'Égypte, vol. I (Cairo, 1926), 196; Nigel Strudwick, The Administration of Egypt in the Old Kingdom, The Highest Titles and their Holders, Studies in Egyptology (London, 1985), 142. ${ }^{8}$ Karol Myśliwiec and Kamil Kuraszkiewicz, The Funerary Complex of Nyankhnefertem, Saqqara, IV, Polish-Egyptian Archaeological Mission (Warszawa, 2010), 128. niche. Although the tomb owner has two or three names, like most of the individuals in the Old Kingdom, ${ }^{9}$ only one name is mentioned in this sunshades scene. His other name/names are 'Shepspuptah', which is only mentioned in the chapel and/or 'Ptahshepses', which is only inscribed in the burial chamber. It is mentioned in the chapel that Shepspuptah is the $r n$ 3 'the great name'. The sign $\square$ at the end of the name is probably a phonetic complement for the word šss. So, the name 'Shepspuptah' could be 'Ptahshepses'. The first title of the attendant who is incensing the deceased, imy-ht $p r-c\}$, is also held by the tomb owner. His name, Nyhesba, is not attested in Ranke's or Scheele-Schweitzer's study. But this recently discovered tomb of Ptahshepses proves that this name was attested in the Old Kingdom.

\section{The scene of the tomb owner sheltered by the sunshades}

The tomb owner is sitting, standing, walking, or being transported and sheltered from the sun's heat by a sunshade, kiosk, ${ }^{10}$ or canopy on top of the palanquin. ${ }^{11}$ The sunshade is depicted accompanying the tomb owner in Old Kingdom private tombs on two different occasions; when he is transported in the palanquin, ${ }^{12}$ or when he was standing or walking on the ground. Pthashepses' scene belongs to the second type. This scene of the deceased is standing or walking while sheltered by a sunshade, is found in the Memphis Necropolis and provinces in about nine tombs; Nihetep-Ptah G 2430/LG 25, ${ }^{13}$ Nimaetre $^{14}$ and Khafreankh G 7948/LG $75^{15}$ at Giza, Hetepherakhti, ${ }^{16}$ Niankhkhnum and Khnumhotep, ${ }^{17}$ Mereruka ${ }^{18}$ and Pthashepses, the recently discovered one and the subject of this article, at Saqqara,

\section{${ }^{9}$ Scheele-Schweitzer, Personennamen, 733 [3702].}

${ }^{10}$ Ahmed Moussa and Friedrich Junge, Two Tombs of Craftsmen, Old Kingdom Tombs at the Causeway of King Unas at Saqqara, Archäologische Veröffentlichungen 9 (Mainz am Rhein, 1975), 18, pl. 3; Naguib Kanawati, Deir El-Gebrawi, vol. I, The Northern Cliff, The Australian Centre for Egyptology: Report 23 (Oxford, 2005), pl. 63, vol. 2 (Oxford, 2007) pl. 72.

${ }^{11}$ Oxford Expedition to Egypt (OEE) Database, <http://www. Oxfordexpeditiontoegypt.com/ Database.php> OEE. 11.7.1

${ }^{12}$ OEE. 11.7.7.

${ }^{13}$ Alexander Badawy, The Tomb of Nyhetep-Ptah at Giza and the Tomb of cAnkhmcahor at Saqqara, University of California Publications: Occasional Papers No. 11: Archaeology. University of California Press (Berkeley, Los Angeles and London, 1978), 3, fig. 5; Bertha Porter and Rosalind Moss, Topographical Bibliography of Ancient Egyptian Hieroglyphic Texts, Reliefs and Paintings, vol. III, Memphis, Part I, Abû Rawâsh to Abûșîn ( $2^{\text {nd }}$ edition, Oxford, 1974), 94.

${ }^{14} \mathrm{PM}$. III' ${ }^{2}$ 283; Selim Hassan, Excavations at Gîza 1930-1931, Vol. II (Cairo, 1936) 220-1, fig. 240.

${ }^{15}$ Karl Lepsuis, Denkmäler aus Aaegyptien und Aethiopien, Planches, II (Berlin, 1972) 9; PM. III², 207-8.

${ }^{16}$ Bertha Porter and Rosalind Moss, Topographical Bibliography of Ancient Egyptian Hieroglyphic Texts, Reliefs and Paintings, vol. III, Memphis, Part II, Șaqqâra to Dahshûr, fasc. 2 ( $2^{\text {nd }}$ edition, Oxford, 1979), 593; Herta Mohr, The Mastaba of Hetep-her-akhti, Study on an Egyptian Tomb Chapel in the Museum of Antiquities, Leiden, Mededeelingen en Verhandelingen No. 5 (Leiden, 1943) 78-79, fig. 44.

${ }^{17}$ Ahmed Moussa and Hartwig Altenmüller, Das Grab des Nianchchnum und Chnumhotep, Old Kingdom Tombs at the Causeway of King Unas at Saqqara, Archäologisches Veröffentlichungen 21 (Mainz/Rhein, 1977), 128-29, pl. 55; PM. III' ${ }^{2}, 641-44$.

${ }^{18}$ Bertha Porter and Rosalind Moss, Topographical Bibliography of Ancient Egyptian Hieroglyphic Texts, Reliefs and Paintings, vol. III, Memphis, Part II, Șaqqâra to Dahshûr, fasc. 1 ( $2^{\text {nd }}$ edition, Oxford, 1978), 525-34; Prentice Duell, The Mastaba of Mereruka, Part II (Chambers A1-10, Plates 104-219), Oriental Institute Publications. vol. XXXIX (Chicago, 1938) pls. 166, 167; Naguib Kanawati, Alexandra Woods, Sameh Shafik and Effy Alexakis, Mereruka and his Family, Part III: 2, The Tomb of Mereruka, The Australian Centre for Egyptology: Report 30 (Oxford, 2011) pl. 82. 
Meru at Sheikh Said ${ }^{19}$ and Hemre/Izi at Deir el-Gebrawi. ${ }^{20}$ There is another scene of a person standing on the ground sheltered by the sunshade in the tomb of Nefer and Kahay at Saqqara. ${ }^{21}$ We disagree with Moussa and Altenmüller, ${ }^{22}$ Porter and Moss, ${ }^{23}$ and Lashien ${ }^{24}$ who consider this person is an overseer inspecting and supervising the work. But we suggest it is for Nefer, Kahay or another member of the owners of this family's tomb, because this kind of scene is appropriate for the tomb owner and not for an overseer or attendant. Also his size is greater than the people around him.

This scene appeared from the middle of the Fifth Dynasty (Khafreankh), onwards (Hetepherakhti, Niankhkhnum and Khnumhotep, Nefer, Nimaetre, Mereruka, Nihetep-Ptah and Hemre) till the late of the Sixth Dynasty (Meru). Pthashepses' tomb belongs to the end of the Fifth Dynasty and the beginning of the Sixth Dynasty. This scene is usually connected to male tomb owners and occurred only once in the same tomb. It is more often depicted on the east wall (Nimaetre, Khafreankh, Niankhkhnum and Khnumhotep, Nefer and Mereruka). Sometimes, though, it can be seen on the west (NihetepPtah), south (Hetepherakhti), or north (Hemre) walls or thickness of an entrance (Meru) of the tomb super-structure. Ptahshepses' scene was depicted on the east wall.

The scene consists of all these main elements: the tomb owner, one or two sunshades and one or two of the sunshade-carriers. Some scenes include these secondary elements; one or two of the family members (Nimaetre, Hetepherakhti, Niankhkhnum and Khnumhotep, Mereruka and Hemre), guards (Mereruka), a bearer of the tomb owner's tools; the flywhisk, throwing-stick (NihetepPtah), bag and sandals (Hetepherakhti) and one dog (Khafreankh). Ptahshepses' scene includes the tomb owner, two sunshades, two of the sunshade-carriers and one is censing the tomb owner. This is the only tomb which includes this man. The tomb owner is always standing and occurs in four different positions: holding the staff and the handkerchief (Nihetep-Ptah, Niankhkhnum and Khnumhotep and Mereruka), holding the staff and the scepter (Meru and Hemre), leaning on the staff in a relaxed attitude (Nimaetre, Khafreankh and Nefer) and holding a flywhisk in one hand and touching his kilt with the other (Ptahshepses). The deceased is shown either with a shoulder-length wig (Khafreankh, Hetepherakhti, Niankhkhnum and Khnumhotep and Hemre), or bareheaded (Nimaetre, Nihetep-Ptah and Nefer). Ptahshepses' scene belongs to the first style.

The deceased appears either with a beard (Hetepherakhti and Niankhkhnum - Khnumhotep), or without it (Nimaetre, Nihetep-Ptah, Khafreankh, Nefer and Meru). Ptahshepses' scene belongs to the first style, which maybe is a character connected to Saqqara tombs. The deceased is depicted with either with a necklace (Nimaetre, Hetepherakhti, Niankhkhnum and Khnumhotep, Nefer and Hemre),

\footnotetext{
${ }^{19}$ Norman Davies, The Rock Tombs of Sheikh Said, Archaeological Survey of Egypt, Tenth Memoir (London, 1901) pl. v; Bertha Porter and Rosalind Moss, Topographical Bibliography of Ancient Egyptian Hieroglyphic Texts, Reliefs, and Paintings, vol. IV, Lower and Middle Egypt (Delta and Cairo to Asyut) ( $1^{\text {st }}$ edition, Oxford, 1934), 189.

${ }^{20} \mathrm{PM}$. IV $\mathrm{I}^{1}, 243$; Kanawati, Deir El-Gebrawi, I, pl. 47.

${ }^{21} \mathrm{PM}$. III', 639-41; Ahmed Moussa and Hartwig Altenmüller, The Tomb of Nefer and Ka-hay, Old Kingdom Tombs at the Causeway of King Unas at Saqqara, Archäologische Veröffentlichungen 5 (Mainz/Rhein, 1971), 27, pl. 18; Miral Lashien, The Chapel of Kahai and his Family, The Australian Centre for Egyptology: Report 33 (Oxford, 2013), 36, pls. 32, 78.

${ }^{22}$ Moussa and Altenmüller, Nefer, 27.

${ }^{23} \mathrm{PM}$. III', 640 (3).

${ }^{24}$ Lashien, Kahai, 36.
}

or without it (Nihetep-Ptah and Khafreankh). Ptahshepses' scene belongs to the first style. The deceased is, as a rule, shown with a projecting kilt. Sometimes he is wearing a leopard's skin upon this kilt (Meru and Hemre), or a sash over his shoulder (Khafreankh). Ptahshepses' scene belongs to the first and common style. The deceased is generally manifested without sandals (Nimaetre, Khafreankh, Mereruka, Meru and Hemre). Sometimes, though, he is wearing sandals (Hetepherakhti, Niankhkhnum and Khnumhotep and Nefer). Ptahshepses' scene belongs to the first and common style. The scene usually includes one sunshade carrier (Nimaetre, Khafreankh, Nihetep-Ptah, Hetepherakhti, Niankhkhnum and Khnumhotep, Nefer, Meru and Hemre) and rarely two (Mereruka). Ptahshepses' scene belongs to the rare type. The sunshade carrier is generally depicted behind the tomb owner (Nimaetre, Nihetep-Ptah, Hetepherakhti, Niankhkhnum and Khnumhotep, Nefer and Hemre), sometimes in front of him (Khafreankh and Meru), or in both positions (Mereruka). Ptahshepses' scene belongs to the last style. The sunshade carrier is represented wearing three different kilts: the short and tight kilt (Khafreankh, Hetepherakhti, Mereruka, Nefer and Meru), or the striped kilt (Niankhkhnum and Khnumhotep), or the projecting kilt (Mereruka and Hemre). In Ptahshepses' scene, the sunshade-carriers wear the second style of kilt (the striped kilt).

The sunshade consists of a mat or a cloth hanging at the rear and stretched over two crossing bars lashed to the top of a slanted pole..$^{25}$ It is necessary for the tomb owner's outdoors activities. ${ }^{26}$ There are some inscriptions following the scene: a description of the action (Nimaetre, Nihetep-Ptah and Hetepherakhti), the offering formula (Hemre), the titles and the name of the next persons; the tomb owner (Nimaetre, Khafreankh, Nihetep-Ptah, Hetepherakhti, Niankhkhnum and Khnumhotep and Hemre), his family members (Hetepherakhti, Niankhkhnum and Khnumhotep, Mereruka and Hemre) and the title of the attendant (Nimaetre, Nihetep-Ptah and Hetepherakhti). Ptahshepses' scene has his title and name and his attendants' titles and names. There are no inscriptions in the scene of Nefer. In this scene, the tomb owner is usually going to inspect his possessions on a hot day: ${ }^{27}$ the work in his fields and storing the crops (Nimaetre, Mereruka, Hetepherakhti and Niankhkhnum and Khnumhotep), the work in his gardens and orchards (Hemre), boatmen jousting (Nimaetre), supervising the workshop activities (Nefer), or reading the reports and accounts of his possessions and watching them (Khafreankh and Hemre). In Ptahshepses' scene, there is no any activity depicted in front of the tomb owner or text referring to the action, but adjacent reliefs show Ptahshepses being transported in a palanquin along with bed and chair preparation, oil-jars, bearers of linen, oil, fan and boxes, cow is giving birth, milking a cow, hobbled and tethered calves, workers pouring grain into a poultry house for geese or ducks and making bread and cooking. So Ptahshepses is coming to supervise and watch the placing of funerary furniture in his tomb. Also he is coming to inspect his pastures and poultry-yard and to watch preparing the food and offerings.

\section{Acknowledgements}

None.

\section{Conflict of interest}

Author declares that there is no conflict of interest.

\footnotetext{
${ }^{25}$ Badawy Nyhetep-Ptah 3.

${ }^{26}$ Kanawati, Deir El-Gebrawi, I, 49.

${ }^{27}$ Badawy, Nyhetep-Ptah, 3.
} 